\title{
EVALUATION OF REGIONAL TRAINING CENTER PROGRAM (PUSLATDA) KONI SOUTH SUMATRA PROVINCE TO FACE UPON PON XIX JAWA BARAT
}

\author{
Herri Yusfi
}

\begin{abstract}
The purpose of this study was to evaluate context, input, process, and product of Puslatda program in South Sumatra at PON XIX 2016 in West Java. This research was an evaluation research. The subject of research, namely management of KONI south Sumatra, sport branch, trainers, and athletes of sports included in Puslatda program South Sumatra with the amount of 137 people. Data collection techniques used in this study was using interviews, questionnaires, and documentation. Sampling technique used for this study was purposive sampling technique. The data analysis technique used in this study was using qualitative and quantitative descriptive analysis.The result of this study was concluded that the overall result of the evaluation ofPuslatdaprogram in South Sumatra to face upon PON XIX 2016 in West Java is in sufficient category. The explanation of the resultsare: (1) Context evaluation shows good category, clear program planning, presence of goals and objectives in Puslatda program, and vision and mission during Puslatda. (2) the evaluation of inputs is in sufficient category, (3) the evaluation of the process is in sufficient category, the suitability of implementation details of the program and many implementation activities are not in accordance with description of the program tasks; and (4) the evaluation of the products are showing the achievement of the overall Puslatda program is considered in poor category, judged from the achievements of South Sumatra athletes in PON XIX West Java which is not in accordance with the target.
\end{abstract}

Keywords: Program Evaluation, Regional Training Center (PUSLATDA).

Sports achievement is one reflection of a nation, sports achievement can make the name of the nation and the country become great in the world so as to enhance the dignity of a nation. Success in sporting achievements is influenced by many factors, and each factor also influences one another, increasing the complexity of achievement and coaching problems. The main program to achieve sporting achievement is to gain talented athletes, training with competent trainers, supported by adequate facilities and infrastructure, through science and technology-based approaches, and managing healthy and professional organizations.

Achievement in sport is actually something that observable and measurable, that is if sport coaching is conducted with a scientific approach (scientific approach) ranging from talent scouting (talent scouting) to the process of 
coaching accompanied by efforts to scrutinize the competitors, then we can ensure its success rate. The process of fostering and developing sports is a systematic conscious effort to achieve sporting objectives (National Sports System Act No. 3, 2005). One sporting goal is to improve sports performance. In achieving the achievement required the existence of coaching as early as possible through search, monitoring talent, breeding, education and training of sports based on science and technology more effectively to improve the quality of sports organizations both central and regional levels.

Achievement of sport in Indonesia is inseparable from the role of coaching sports achievements that exist in each region, including sports coaching achievements in the Region of South Sumatra. One of the measurements of sports achievements of each region is the achievements achieved in the implementation of the National Sports Week (PON). South Sumatra's rank since PON 1993 until PON 2012 in Riau tends to decrease. Rank 5 is the highest rank ever achieved by contingent South Sumatra, namely at PON 2004 in South Sumatra. After that the contingent of South Sumatra never reached the top 6. The lowest rank occurred in PON 1996, South Sumatra ranks 19th out of 27 provinces in Indonesia. And in PON 2012 in Riau, South Sumatra was thrown to position 13 of 33 provinces, where in 2004 and in 2005 South Sumatra can reach the top 10 rankings. Graph 1 shows the contingent achievements of South Sumatra during PON.

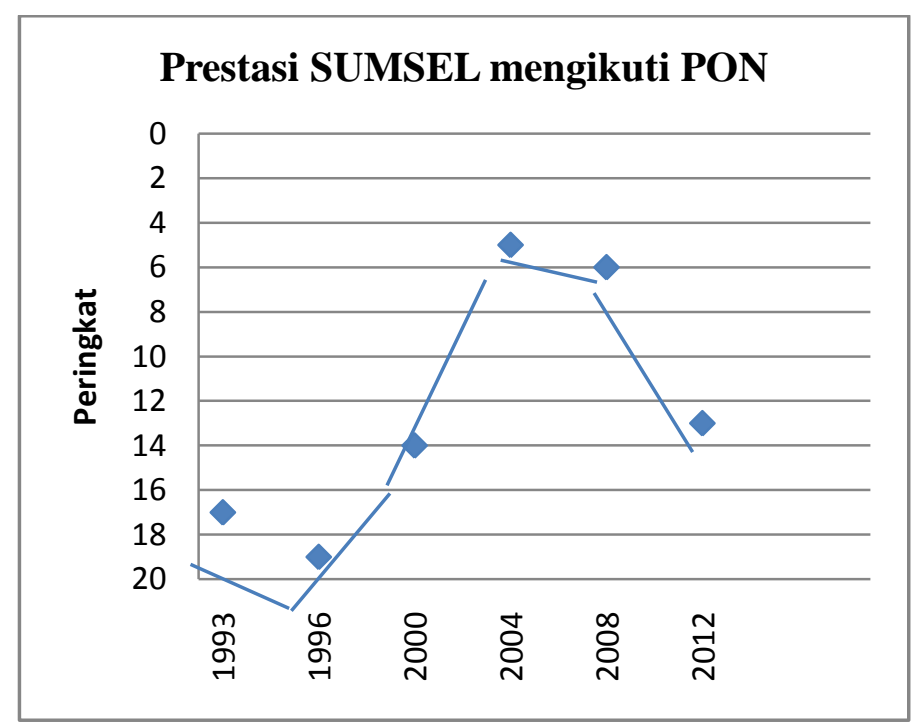

Figure 1. SUMSEL Achievement at PON from 1993 to 2012

Source :Kemenpora. Presentation of Information Data of State Ministry of Youth and Sport 2008. (Jakarta: Kemenpora: 2008), p.112-116

Achievements obtained are the impact of the coaching process that has been done. In the process of coaching or training there are very complex variables. 
These variables include, among others, preparation and planning exercises conducted by trainers, training process, support facilities, athlete motivation and others. Achievement sports coaching program seen since 1993-2012 has not shown maximum results. The best South Sumatra rankings are only ranked 5th in 2004 where South Sumatra hosts the PON XVI. In the following year South Sumatra was ranked 6th and at PON 2012 in Riau was thrown to 13th position, out of target to occupy the top ten position. Judging from the medal achievement in each PON South Sumatra contingent tends to decrease.

Several factors are very influential in the development of sports achievements, namely; (1) acquiring talented athletes, (2) training with competent trainers, (3) adequate facilities and infrastructure, (4) approaches based on science and technology, and (5) managing healthy and professional organizations. So good management of Puslatda will affect the quality of athletes and coaches that are produced. Therefore, the implementation of KONI management in the puslatda program followed by all athletes in South Sumatra must have standardization.

Procurement of this Puslatda program, KONI South Sumatra target is to enter the top 10 in PON 2016 in West Java. The success of coaching athletes can be monitored from the achievements achieved in a championship, however good the training program is applied, if in the championship they can not record the achievement, then the coaching can not be said successful, Governor of Yogyakarta Special Region (DIY) Sultan Hamengkubuwono X in his speech at Sports performance guidance manual. So it is necessary to do a scientific study on how the management of resources components involved in this Puslatda program that is by conducting an evaluation program Puslatda KONI South Sumatra Province in the face of PON XIX 2016 in West Java.

The SWOT program (strengths, weaknesses, opportunities, and threats) is a method used to analyze or evaluate the strengths, weaknesses, opportunities and threats in a championship.

Taking into account the characteristics of Puslatda South Sumatra Province and SWOT analysis results it is necessary to make an effort to realize the Puslatda program in accordance with expectations. One of the fundamental steps of this evaluation is due to the importance of empirical data on how South Sumatera's KONI management is in the Puslatda program, and also because the program is something that is dynamic, changing and evolving in accordance with the development of science and the demands of community change. To find out the changes and the development of these, an evaluation is needed in order to refine the program in accordance with the development and demands of the change.

\section{Research Focus}

The focus of this evaluation study is to evaluate the management of Puslatda program of KONI South Sumatera Province which covers 5 (five) management functions, namely planning, organizing, supervising and evaluation. The evaluation model approach uses context, input, process and product 
components. In the context component, the focus on planning is divided into 4 subfocuses: program planning, goals, vision and mission and legal basis. In the input component, the focus on organizing consists of 4 sub-focuses: organizational structure, coaching program, athlete recruitment, trainer recruitment. In the process component, the focus on organizing consists of 7 sub-focuses: program funding, infrastructure, funds, training program, needs analysis, trainer quality improvement, workplace eligibility, supporting media. In the product component, the focus on organizing consists of 2 sub-focus of supervision and achievement.

\section{Formulation of the Problem}

This study is a research evaluation of program management of Puslatda KONI South Sumatera Province which is reviewed by context, input, process, product so that problems which can be formulated in this research are as follows:

a. Context

1. How is the planning of management program atPuslatda KONI South Sumatra Province?

2. How is the purpose of management program atPuslatda KONI South Sumatra Province?

3. How is the vision and mission of management program atPuslatda KONI South Sumatra Province?

4. What is the legal basis of management program at Puslatda KONI South Sumatera?

\section{b. Input}

1. How is the organizational structure of management at Puslatda KONI in South Sumatera Province?

2. How is the training program at Puslatda KONI South Sumatra Province?

3. How is the recruitment of athletes at Puslatda KONI South Sumatra Province?

4. How is the recruitment of trainers at Puslatda KONI South Sumatera Province?

\section{c. Process}

1. How is the funding aofPuslatda KONI program in South Sumatera Province?

2. How is the infrastructure of Puslatda KONI program in South Sumatera Province?

3. How is the training program of Puslatda KONI program in South Sumatera Province?

4. How is demand analysis of Puslatda KONI program of South Sumatera Province?

5. How to improve the quality of trainers at Puslatda KONI program in South Sumatra Province?

6. How is the training place feasibility of Puslatda KONI program in South Sumatra Province? 
7. How is media support for Puslatda KONI program in South Sumatra Province?

\section{d. Product}

1. How is the supervisory system of Puslatda KONI program in South Sumatera Province?

2. How is the achievement achieved by Puslatda KONI in South Sumatra Province?

\section{Theoretical Study}

The evaluation of the program has a meaning related to the application of the scale of value to the outcome of the policy or program that has been implemented. A simple description of the evaluation is the process of achieving the objectives of the implementation of the program. Evaluation of the program itself serves to determine the achievement of a program, but it can also be used as a basis for carrying out follow-up activities in taking a next policy.

Sukardi explained that the evaluation is developed through the following management:

Program evaluation is also developed from several management pillars or management concepts, namely: monitoring, evaluation, and control. An institution needs a good plan for its potential to lead to the goal, by mobilizing all available resources.

Meanwhile, according to Daniel L. Stufflebeam and Chris L. S. Coryn, concept of evaluation is:

Evaluations based on randomized experiments can result from competing programs, products, or services. However, in many evaluations, a controlled experiment would not be feasible, or it would be counterproductive; It might be unethical; Or it might fail to address key questions about needs, objectives, plans, processes, side effects, and other important aspects of a program.

Paton explains that program evaluation is a systematic data retrieval process for assessing and deciding a program. In addition, according to Widiastuti evaluation is the process of placing values on a measurement. This involves or compares scores with the scale and value implanted. Evaluations may use a normative scale (relative) derived from the score of paired groups or from the standard (absolute) scale that requires participants to perform at a standard level of applied results.

According to James Tangkudung the evaluation of the program is focused into several things, namely:

Evaluation is focused on an activity in one particular unit, the activity can be program, process or work result, place, organization, or institution. While the program is a system that is not done only once but on an ongoing basis.

Based on some of these opinions it can be concluded that the evaluation program is a process, where the process must be systematic in the data retrieval. Evaluation is used for decision making or assessment. So the evaluation of the 
program has three important things, namely data retrieval, assessment, and decision making.

Program evaluation is often used to determine the effectiveness of the program, where effectiveness describes the extent to which a program or initiative that meets the expected results, and to inform action.

Attempts to engage in activities should address four basic principles, as suggested by Daniel L. Stufflebeam namely utility, feasibility, propriety, and accuracy. The explanation is as follows:

1. Utility is meant to make the evaluation that is informative.

2. Feasibility is intended for evaluation design to be arranged in accordance with the field to be evaluated and cost effectively.

3. Propriety is meant for evaluation to be done legally and uphold ethics. Accuracy is intended for evaluation to be accurate and valid, reliable, and comprehensive information.

The evaluation model is used to carry out evaluation of the program to be evaluated. (1) Model Evaluation of Countenance, (2) Logic Model, (3) Wholey Evaluation Model, (4) CSE-UCLA Model, (5) CIPP Model, (6) Discrepancy Model, And (7) Responsive Evaluation Model.

\section{Model Evaluation Program Used}

The model used in this research is a decision model developed by Stufflebeamknown as CIPP Evaluation Model.The CIPP model (context, input, process, product) was developed by Daniel L. Stufflebeam. He defines evaluation as a systematic process in describing, obtaining, providing useful information for assessing decision-making alternatives. Obtaining information in evaluation by means of collecting, organizing, and analyzing information and synthesizing it so that the information obtained can be used as a consideration of stakeholders in evaluation.

CIPP model consists of four types of evaluation, namely context, input, process, and product. Explanations of each type are as follows:

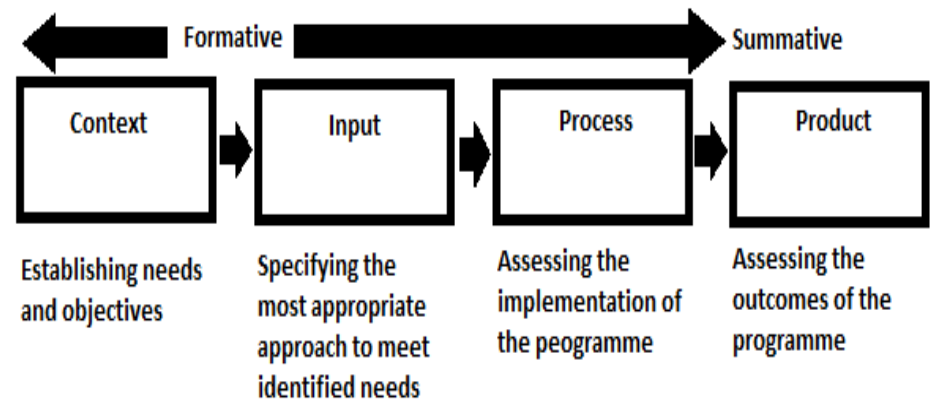

Figure 2.5.CIPP Evaluation Model.

(Source: kompasiana.com)

Context or Contexs is an attempt to describe and detail the environmental needs. Specifically Daniel L. Stufflebeam provides an explanation that context 
evaluation needs assessment, problems, assets, and opportunities to help decision makers define goals and priorities and help the broader group of users judge goals, priorities, and outcomes. The explanation means that the Contexs evaluation assesses the needs, problems, assets, and opportunities to assist decision-making in defining objectives and priorities and assisting broader groups for priority objectives and outcomes. The purpose of context evaluation is to define the relevant context, identify the target population and assess Needs, identify opportunities to meet needs, diagnose problems that underlie needs, and assess whether program objectives meet the needs.

Input is used to identify needs in running programs or policies. Evaluation of process components is used to provide feedback regarding the efficiency of program or policy implementation, including the influence of the system and its implementation. Product evaluation is the final stage of a series of CIPP evaluations.

The advantages of CIPP evaluation are (a) this model identifies and assesses expected and unwanted results in both the short and long term; (B) the model is more comprehensive among other evaluation models, this is because the evaluation object is not only for the results but also includes the Contexs, inputs, processes, and products or results; And (c) have the potential to move in the areas of formative and summative evaluation. So it is equally good in helping to make improvements during the program, as well as providing the final information.

\section{METHODS OF STUDY}

\section{Types of Evaluation}

Based on the research problem proposed, this type of research belongs to the evaluation research. This research uses mixed methods or combines quantitative and qualitative methods, and is deepened by qualitative methods. This evaluation study is an activity to collect data, presenting accurate and objective information about the management of Puslatda KONI program of South Sumatera Province in the face of PON. So the information obtained can determine the value or success rate of the program, so it can be useful in providing advice or recommendation whether the program KONI South Sumatra Province is necessary to be continued, improved and modified.

\section{Evaluation Model Used}

The evaluation model used is Context, Input, Process, Product (CIPP), a model developed by Stufflebeam, et al (1967). Evaluation is a process to find out how far the planning can be done and how far the program objectives are achieved. The evaluation results are not intended to replace the program, but rather to select and give consideration to the program components that need to be improved. The information obtained is a feedback that can be used to improve the program.

The design of this program evaluation study refers to the CIPP model. Which in this design should carry out four types of evaluation, namely: evaluation 
of contexs, input evaluation, process evaluation, and product evaluation. The stages and types of evaluation process of CIPP Model and its influence in improving the system is detailed in the following figure:

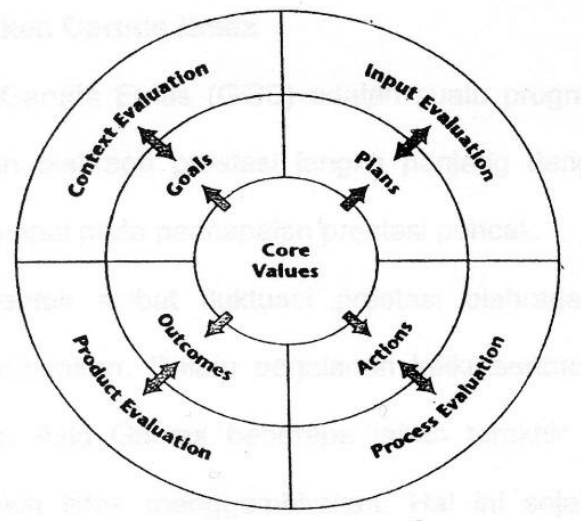

Figure 12. Stages and Processes Types of CIPP Evaluation Model As Well As

\section{Its Influence In System Upgrades}

Source: James Tangkudung., Macam-Macam Metodologi Penelitian (Uraian dan Contohnya), (Jakarta: Penerbit Lensa Media Pustaka Indonesia, 2016), h. 90.

This model is used because it is comprehensive because the object of evaluation is not only on the final result but will involve input and process. The use of this method is determined by the type of data that needs to be filtered, such as the time required in the execution of evaluation, Source of energy, Source of cost, and Source of information.

\section{Place and Time of Evaluation}

This research was conducted in South Sumatera region and the time needed in this research is about 6 months, it is estimated starting from May until November.

Population and Sample Evaluation

1. Source of data in this research is, as follows:

a. Chairman of KONI South Sumatera (Vice Chairman 2 KONI South Sumatera).

b. General Treasurer of KONI South Sumatra Province.

c. Chairman Bimpres of KONI South Sumatra

d. Officials of sports branch

2. Triangulation of data (trainer Interview, athlete questionnaire, and documentation).
a. Athletes from sports
b. Coaches from sports
c. Documentation
1) Implementation of the exercise
2) Facilities
3) Infrastructure 
4) Achievement of PON

5) Organizational structure

6) Training program

\section{Data Collection Techniques and Instruments used Data collection technique}

In this research, triangulation technique is used by trying to evaluate phenomenon relevant with research problem, data collecting technique used in this evaluation research is by method (a) interview, (b) questionnaire, and (c) documentation.

a. Interview

Interviews or often called interviews or verbal questionnaire, is a dialogue conducted by the interviewer to obtain information from the interviewee. This study is using interviews / free-guided interviews, which is a combination of free and guided interviews that carry the implementation of the guidelines that are only an outline of the things that will be asked.

b. Questionnaire

This instrument is used to capture research data by asking questions or statements.Akket given directly. Once the respondents live answer what is asked about him, namely: aspects that are reviewed from the human resources sports, facilities, infrastructure, and government policies of South Sumatra. Questionnaires for athletes were used to obtain data on athletes' athletes, number of local athletes, national athletes, international athletes, and existing achievements in each sport, obstacles and athletic achievements during the Bapomi program.

c. Documentation

Documentation is derived from the word document, which means the items are written. In carrying out the method of documentation, researchers investigate written objects such as books, regulations, diaries, etc..

This documentation technique is used to collect or load data on facilities and infrastructure, the results of the medal achievement of each sports branch ever achieved athletes in the National Sports Week. These data will strengthen the results of research in relation to the problems that have been raised in this study.

\section{Instrument Development}

This research is an evaluation of management of Puslatda KONI South Sumatra Province in facing PON. This issue is explored through CIPP evaluation. In the evaluation of the context will be explored data on objectives, targets, training programs, structure and organizational structure, and the division of tasks in the program Puslatda. Evaluation of this context will be explored through interviews, questionnaires, and documentation. Evaluation of inputs will explore the availability of trainers and athletes, availability of time, availability of budget allocations and their use, and the availability and feasibility of infrastructure and 
facilities in training programs in preparation for PON. The evaluation of these inputs will be explored using interviews, questionnaires, and documentation.

Evaluation process will explore the suitability of the details of the implementation of the training program with the implementation of the exercise to see how the implementation process in the program progresses, the implementation activities in accordance with the description of program tasks, and monitoring activities.

Evaluation of this process will be explored through interviews, questionnaires, and documentation. The product evaluation will explore data on the achievement of organizational management, goals, and objectives in the Bapomi program. Evaluation of this product will be explored through interviews, questionnaires, and documentation.

\begin{tabular}{|c|c|c|c|}
\hline $\begin{array}{l}\text { Evaluation } \\
\text { Componen }\end{array}$ & Sub Componen & Indicator & Criteria of Success \\
\hline Context & $\begin{array}{l}\text { 1. Plan of } \\
\text { KONI } \\
\text { 2. Purpose of } \\
\text { the program } \\
\text { 3. Vision and } \\
\text { Mission of } \\
\text { the Program } \\
\text { 4. Legal Basis }\end{array}$ & $\begin{array}{l}\text { 1. Conformity of } \\
\text { the legal basis } \\
\text { 2. Conformity } \\
\text { between } \\
\text { program } \\
\text { objectives and } \\
\text { policies } \\
\text { 3. The suitability } \\
\text { of the athlete's } \\
\text { needs } \\
\text { 4. SK of KONI } \\
\text { 5. Target of } \\
\text { KONI }\end{array}$ & $\begin{array}{l}\text { 1. There is an organizational } \\
\text { structure. } \\
\text { 2. There is an organizational } \\
\text { structure. } \\
\text { 3. There is a job description } \\
\text { 4. There is SK of KONI } \\
\text { 5. There is a vision and } \\
\text { mission } \\
\text { 6. There is a program } \\
\text { objective }\end{array}$ \\
\hline Input & 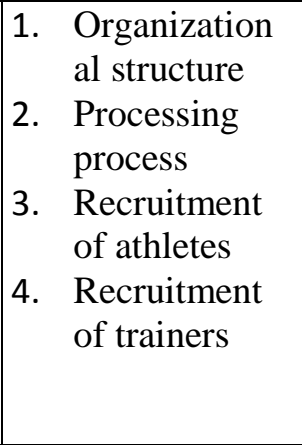 & $\begin{array}{l}\text { 1. Professional } \\
\text { athlete's power } \\
\text { 2. Talented } \\
\text { athlete } \\
\text { 3. Time } \\
\text { availability }\end{array}$ & $\begin{array}{l}\text { 1. Availability of certified } \\
\text { national trainers } \\
\text { 2. Availability of athletes by } \\
\text { selection } \\
\text { 3. Sufficient time available } \\
\text { from routine running } \\
\text { budget } \\
\text { 4. Fulfilled and adequate } \\
\text { amount of available } \\
\text { facilities and infrastructure }\end{array}$ \\
\hline Process & $\begin{array}{l}\text { 1. Funding of the } \\
\text { puslatda } \\
\text { program } \\
\text { 2. Facilities and } \\
\text { infrastructure } \\
\text { 3. Exercise } \\
\text { program } \\
\text { 4. Needs }\end{array}$ & $\begin{array}{l}\text { 1. Implementatio } \\
\mathrm{n} \text { in } \\
\text { accordance } \\
\text { with the } \\
\text { exercise } \\
\text { program } \\
\text { 2. Activity } \\
\text { implementatio }\end{array}$ & $\begin{array}{l}\text { 1. Schedule of the } \\
\text { implementation of activities } \\
\text { in accordance with the } \\
\text { exercise program } \\
\text { 2. Description of the task in } \\
\text { accordance with the } \\
\text { standards set by the } \\
\text { chairman }\end{array}$ \\
\hline
\end{tabular}




\begin{tabular}{|c|c|c|c|}
\hline & $\begin{array}{l}\text { analysis } \\
\text { 5. Improved } \\
\text { quality of } \\
\text { trainers } \\
\text { 6. The feasibility } \\
\text { of training } \\
\text { 7. Activity in } \\
\text { implementatio } \\
\mathrm{n} \text { accordance } \\
\text { with the } \\
\text { description of } \\
\text { program } \\
\text { duties }\end{array}$ & $\begin{array}{l}\text { n in } \\
\text { accordance } \\
\text { with the } \\
\text { description of } \\
\text { program } \\
\text { duties } \\
\text { 3. Feasibility of } \\
\text { facilities and } \\
\text { infrastructure } \\
\text { 4. Quality } \\
\text { trainers } \\
\text { 5. Funding of } \\
\text { KONI in } \\
\text { puslatda } \\
\text { program }\end{array}$ & $\begin{array}{l}\text { 3. The quality of infrastructure } \\
\text { and facilities used meet } \\
\text { national standards } \\
\text { 4. Implementation in } \\
\text { accordance with the training } \\
\text { program planned by the } \\
\text { trainer }\end{array}$ \\
\hline Product & $\begin{array}{l}\text { 1. Program } \\
\text { supervision } \\
\text { 2. Increased } \\
\text { athlete's } \\
\text { condition } \\
\text { 3. Athlete } \\
\text { achievement }\end{array}$ & $\begin{array}{l}\text { 1. Achievement } \\
\text { of } \\
\text { organizational } \\
\text { management } \\
\text { of puslatda } \\
\text { program } \\
\text { 2. Achievement } \\
\text { of target of } \\
\text { puslatda } \\
\text { program }\end{array}$ & $\begin{array}{l}\text { 1. Achievement of } \\
\text { organizational management } \\
\text { in accordance with the } \\
\text { decisions or policies of the } \\
\text { chairman of KONI } \\
\text { 2. Achieving the target of } \\
\text { KONI } \\
\text { 3. Achieving goals }\end{array}$ \\
\hline
\end{tabular}

\section{RESULT OF STUDY}

1. Description of Program Evaluation Data of Regional Training Center of South Sumatera Province viewed from Context Variable

The following will present the results of the data analysis of organizers, coaches and athletes. Context variables include subcomponents

- Policy of puslatda with indicator of secretariat of puslatda, organizational structure, SK puslatda, job description of board,

- Needs to be achieved by Puslatda program of South Sumatera province with indicator of Target of puslatda and purpose of puslatda).

Table 1.Result of Context Data Collection

\begin{tabular}{|l|l|l|l|l|l|l|}
\hline \multirow{2}{*}{ No } & \multirow{2}{*}{ Sub Componen } & \multirow{2}{*}{ Indicator } & \multicolumn{3}{|l|}{ Data Collection } & \multirow{2}{*}{ Jumlah } \\
\cline { 3 - 7 } & & & W & A & D & \\
\hline 1 & Puslatda Policy & 1. Secretarial & 3 & 3 & 3 & 9 \\
\cline { 3 - 7 } & & 2. Organizational structure & 3 & 3 & 3 & 9 \\
\cline { 3 - 7 } & & 3. Task distribution & 3 & 3 & 3 & 9 \\
\cline { 3 - 7 } & & 4. SK of Puslatda & 3 & 3 & 3 & 9 \\
\hline 2 & Needs to be achieved & 1. Objective of Puslatda & 3 & 3 & 3 & 9 \\
\hline
\end{tabular}




\begin{tabular}{|l|l|l|l|l|l|}
\multicolumn{1}{|c|}{ by Puslatda program } & 2. Target of Puslatda & 3 & 3 & 3 & 9 \\
\hline Total number of Context & & 36 \\
\hline Average of Context & 9 \\
\hline Percentage of Context & $100 \%$ \\
\hline Criteria Context & Good \\
\hline
\end{tabular}

Table2.Criteria of Context Assessment.

\begin{tabular}{|l|l|l|l|}
\hline No & Formula & Range & Criteria \\
\hline 1 & $\mathrm{X} \geq \mathrm{Mi}+\mathrm{Sbi}$ & $\mathrm{X} \geq 7$ & Good \\
\hline 2 & $\mathrm{Mi}-\mathrm{Sbi} \leq \mathrm{X}<\mathrm{Mi}+\mathrm{Sbi}$ & $5 \leq \mathrm{X}<7$ & Sufficient \\
\hline 3 & $\mathrm{X}<\mathrm{Mi}-\mathrm{Sbi}$ & $\mathrm{X}<5$ & Poor \\
\hline
\end{tabular}

$\mathrm{Mi}=4, \mathrm{Sbi}=1$

It can be concluded that Context evaluation consisting of subcomponent of puslatda policy and requirement to be achieved in whole puslatda program result of assessment of context evaluation toward puslatda of South Sumatera Province is good.

1. Description of Program Evaluation Data of Regional Training Center of South Sumatra Province viewed from Input Variables

The following will present the results of the data analysis of organizers, coaches and athletes. Input variables include subcomponents

- Availability of trainers and athletes at Puslatda program is the indicator of professional trainers and talented athletes

- Availability of Puslatda program implementation time is the indicator of available enough time for puslatda program

- Availability of budget allocation and usage is the indicator of Source operational fund of puslatda and operational cost from KONI

- Availability and feasibility of infrastructure and facilities is the indicator of the availability of infrastructure and facilities of puslatda, the feasibility of infrastructure and facilities.

Table 16.Results Input of Puslatda Program in South Sumatra Province

\begin{tabular}{|c|c|c|c|c|c|c|}
\hline \multirow{2}{*}{ No } & \multirow{2}{*}{ Sub Componen } & \multirow{2}{*}{ Indicator } & \multicolumn{3}{|c|}{ Data Collection } & \multirow{2}{*}{ Total } \\
\hline & & & $\mathbf{W}$ & $\mathbf{A}$ & D & \\
\hline \multirow{2}{*}{1} & \multirow{2}{*}{$\begin{array}{l}\text { The availability of } \\
\text { professional trainers } \\
\text { and athletes }\end{array}$} & Professional trainer & 2 & 2 & 2 & 6 \\
\hline & & Talented athlete & 2 & 2 & 2 & 6 \\
\hline 2 & $\begin{array}{l}\text { Availability of } \\
\text { execution time }\end{array}$ & $\begin{array}{l}\text { The time available on the } \\
\text { program }\end{array}$ & 3 & 3 & 3 & 9 \\
\hline
\end{tabular}




\begin{tabular}{|c|c|c|c|c|c|c|}
\hline \multirow{4}{*}{3} & \multirow{4}{*}{ Availability of budget } & Puslatda operational fund & 2 & 2 & 2 & 6 \\
\hline & & Time of disbursement of funds & 2 & 2 & 2 & 6 \\
\hline & & Athlete's Welfare & 3 & 3 & 3 & 9 \\
\hline & & Coach's Welfare & 3 & 3 & 3 & 9 \\
\hline \multirow{5}{*}{4} & \multirow{5}{*}{$\begin{array}{l}\text { Availability and } \\
\text { feasibility of } \\
\text { infrastructure }\end{array}$} & $\begin{array}{l}\text { Availability and Feasibility of } \\
\text { Facilities }\end{array}$ & 2 & 2 & 2 & 6 \\
\hline & & $\begin{array}{l}\text { Completeness of training } \\
\text { facilities }\end{array}$ & 2 & 2 & 2 & 6 \\
\hline & & $\begin{array}{l}\text { Supporting exercise's } \\
\text { equipment }\end{array}$ & 2 & 2 & 2 & 6 \\
\hline & & Supporting ofSport Science & 1 & 1 & 1 & 3 \\
\hline & & $\begin{array}{l}\text { Availability and Feasibility of } \\
\text { Infrastructure }\end{array}$ & 2 & 3 & 2 & 7 \\
\hline \multicolumn{6}{|c|}{ Total } & 79 \\
\hline \multicolumn{6}{|c|}{ Average of Input } & 6,58 \\
\hline \multicolumn{6}{|c|}{ Percentage of Input } & $\begin{array}{c}73,14 \\
\%\end{array}$ \\
\hline \multicolumn{6}{|c|}{ Criteria of Input } & \\
\hline
\end{tabular}

Table 17.Input Assessment Criteria for Puslatda Program in South Sumatera

Province

\begin{tabular}{|l|l|l|l|}
\hline No & Formula & Range & Criteria \\
\hline 1 & $\mathrm{X} \geq \mathrm{Mi}+\mathrm{Sbi}$ & $\mathrm{X} \geq 84$ & Good \\
\hline 2 & $\mathrm{Mi}-\mathrm{Sbi} \leq \mathrm{X}<\mathrm{Mi}+\mathrm{Sbi}$ & $60 \leq \mathrm{X}<84$ & Sufficient \\
\hline 3 & $\mathrm{X}<\mathrm{Mi}-\mathrm{Sbi}$ & $\mathrm{X}<60$ & Poor \\
\hline
\end{tabular}

Ket.Mi $=72$, Sbi $=12$

It can be concluded that the number of evaluation assessments The inputs of the four subcomponents of assessment consisting of 12 assessment indicators, have total number of judgments 79 , seen from Table criteria of assessment of inputs to the South Sumatra provincial puslatda program, Input evaluation is in Sufficient criteria. So it can be concluded that the process of input implementation in the program has many shortcomings.

2. Description of Evaluation Data of Regional Training Center Program in South Sumatera Province in terms of Process Variables

The following will be presented the results of data analysis process board, trainers and athletes. Process variables include subcomponents

- Compliance details of the implementation of Puslatda training program with indicators of training schedule and Try Out 
- Execution activity in accordance with the description of Puslatda program tasks with indicators of implementation activities in accordance with the description of duties of puslatda program, physical test and alet health, nutrition review team athlete, athlete psychology and monitoring activities

Table 20.Results Process of Puslatda South Sumatra Province

\begin{tabular}{|c|c|c|c|c|c|c|}
\hline \multirow{2}{*}{ No } & \multirow{2}{*}{ Sub Componen } & \multirow{2}{*}{ Indicator } & \multicolumn{3}{|c|}{$\begin{array}{l}\text { Data } \\
\text { Collection }\end{array}$} & \multirow{2}{*}{ Total } \\
\hline & & & W & $\mathbf{A}$ & D & \\
\hline \multirow[t]{2}{*}{1} & \multirow[t]{2}{*}{$\begin{array}{l}\text { Compliance details } \\
\text { of implementation of } \\
\text { Puslatda training } \\
\text { program }\end{array}$} & $\begin{array}{l}\text { Implementation in } \\
\text { accordance with the } \\
\text { puslatda training } \\
\text { program }\end{array}$ & 3 & 3 & 3 & 9 \\
\hline & & Try Out & 2 & 2 & 2 & 6 \\
\hline \multirow[t]{5}{*}{2} & \multirow[t]{5}{*}{$\begin{array}{l}\text { Activities } \\
\text { implementation in } \\
\text { accordance with the } \\
\text { description } \\
\text { Puslatda program } \\
\text { duties }\end{array}$} & $\begin{array}{l}\text { Implementation in } \\
\text { accordance with the } \\
\text { description of the } \\
\text { task of the puslatda } \\
\text { program }\end{array}$ & 2 & 2 & 2 & 6 \\
\hline & & $\begin{array}{l}\text { Physical and Athlete } \\
\text { Health Test }\end{array}$ & 2 & 2 & 2 & 6 \\
\hline & & Nutrition of Athletes & 2 & 2 & 2 & 6 \\
\hline & & $\begin{array}{l}\text { Psychological of } \\
\text { Athletes }\end{array}$ & 2 & 2 & 2 & 6 \\
\hline & & $\begin{array}{l}\text { Monitoring of } \\
\text { activities }\end{array}$ & 2 & 2 & 2 & 6 \\
\hline \multicolumn{6}{|c|}{ Total ofProcess } & 45 \\
\hline \multicolumn{6}{|c|}{ Average ofProcess } & 6,42 \\
\hline \multicolumn{6}{|c|}{ Percentage ofProcess } & $71,4 \%$ \\
\hline \multicolumn{6}{|c|}{ Criteria ofProcess } & Fair \\
\hline
\end{tabular}

Table 21.Criteria of Assessment Process

\begin{tabular}{|l|l|l|l|}
\hline No & Formula & Batasan & Kriteria \\
\hline 1 & $\mathrm{X} \geq \mathrm{Mi}+\mathrm{Sbi}$ & $\mathrm{X} \geq 49$ & Good \\
\hline 2 & Mi-Sbi $\leq \mathrm{X}<\mathrm{Mi}+\mathrm{Sbi}$ & $35 \leq \mathrm{X}<49$ & Sufficient \\
\hline 3 & $\mathrm{X}<\mathrm{Mi}-\mathrm{Sbi}$ & $\mathrm{X}<35$ & Poor \\
\hline
\end{tabular}

Mi = 18, Sbi $=3$

It can be concluded that the number of assessment of evaluation process of two subcomponents consisting of 7 assessment indicators has the total score of 45 , it can be seen from table criteria of process assessment of puslatda program South Sumatra that the process evaluation is in sufficient criteria so it can be concluded 
that the process of process implementation in the Puslatda program is well implemented although there are still shortcomings in the implementation.

\section{Description of Evaluation Data of Regional Training Center South Sumatra Province in terms of Product Variable}

Product evaluation in this evaluation uses instrumental criteria related to achievement of short and medium term goals that contribute to the achievement of the final goal of the program (DjujuSudjana, 2006: 56). The results of product evaluation consisting of the achievement of the implementation in accordance with the standards and the achievement of the goal to improve physical, technical, tactical, mental or psychological, health condition and athlete skills as a whole is in good category, so by knowing the results of the data above can be seen that the implementation of the program are in conformity with the established standards and the achievement of program objectives for improving physical, tactical, technical, mental or psychological, health conditions and overall athletic skills.

\section{REFERENCES}

Ariyanto, Muhammad Aziz. (2015). Evaluasi program ManajemenPusatPendidikandanLatihanOlahragaMahasiswa (PPLM) di Jawa Tengah.Disertasi. Jakarta: PPs. UniversitasNegeri Jakarta.

KONI DIY. (2005).Panduanpembinaanolahragaprestasi KONI DIY.Yogyakarta: KONI DIY.

Kemenpora.(2008). Penyajian Data InformasiKementerian Negara PemudadanOlahragaTahun 2008.Jakarta: Kemenpora.

Muhaimin, Mohammad. (2015). "Model Evaluasi CIPP (Context, Input, Process, Product)”. http://www.kompasiana.com/muhaiminmoh/model-evaluasicipp-context-input-process-product_552ab300f1 7e611 530d62496. (diaksestanggal 15 November 2015).

Nana SyaodihSukmadinata.(2014). Metodepenelitianpendidikan. Bandung: RemajaRosdakarya.

Stufflebeam, Daniel L. dan Chris L. S. Coryn. (2014).Evaluation Theory, Models, and Applications. San Fransisco: Jossey-Bass AWiley Brand.

Stufflebeam, Daniel L., Madaus, George F., danKellaghan, Thomas. (2005).Evaluation Models View on Educational and Human Services Evaluation. Boston: Kluwer-Njihoff Publishing.

Stufflebeam, Daniel L. (1994). "Empowerment Evaluation, Objectivist Evaluation, and Evaluation Standards: Where the Future of Evaluation Should not Go and Where it Needs to Go". American Journal of Evaluation, Vol 15 (3), Spring.

SuharsimiArikunto. (2010). Prosedurpenelitian. Jakarta: RinekaCipta.

Sukardi. (2014).Evaluasi Program PendidikandanKepelatihan, Jakarta: BumiAksara.

Tangkudung, James.

(2016).Macam-macamMetodologiPenelitian (UraiandanContohnya). Jakarta: Lensa Media Pustaka Indonesia.

Toho CholikMutohir.,\& Ali Maksum. (2007). Alternatifbarumengukurkemajuanpembangunanbidangkeolahragaan.Jakart a: PT. Indeks. 
Undang-UndangNomor 3 Tahun 2005 tentangSistemKeolahragaanNasional. Widiastut. (2015).Tes dan Pengukuran Olahraga. Jakarta: Rajawali Pers.

Smith, Michael. (2009). A Guide to Planning and Conducting Program Evaluation. Columbia: Foundation for Health Services. 